\title{
Pengaruh Religiusitas Terhadap Gaya Hidup SERAMBI Konsumen M uslim Di Ponorogo
}

\author{
Sumbu Latim Miatun, Lukman Santoso \\ Institut Agama Islam N egeri Ponorogo
}

\begin{abstract}
Purpose- This study aims to determine the effect of religiosity on the lifestyles of Muslim consumers Artomoro stores in Ponorogo. Methods- A total of 97 Muslim consumer respondents at the Artomoro store in Ponorogo were sampled. Sampling uses the Purposive Sampling method, then the data is processed using SPSS 16.0. Data collection instruments using a questionnaire with a Likert scale that has been tested and has met the requirements of validity and reliability. The analytical method used to determine the magnitude of the effect is a simple linear regression. Findings- The results of the study concluded that there is a positive and significant influence between religiosity on lifestyle. The results showed that there was a significant influence of religiosity on the lifestyle of Muslim consumers in A rtomoro shops in Ponorogo by $9.9 \%$ and the remaining $90.1 \%$ was influenced by other variables not discussed in this study.
\end{abstract}

\begin{abstract}
Abstrak
Tujuan- Penelitian ini bertujuan untuk mengetahui pengaruh religiusitas terhadap gaya hidup konsumen muslim konsumen muslim toko Artomoro di Ponorogo. Metode- Sebanyak 97 responden konsumen muslim toko Artomoro di Ponorogo dijadikan sampel. Pengambilan sampel menggunakan metode Purposive Sampling, kemudian data diolah menggunakan SPSS 16.0. Instrumen pengumpulan data menggunakan kuesioner dengan skala likert yang sudah diuji cobakan dan telah memenuhi syarat validitas dan reliabilitas. Metode analisis yang digunakan untuk mengetahui besarnya pengaruh tersebut adalah regresi linier sederhana. Temuan - hasil penelitian menyimpulkan bahwa ada pengaruh positif dan signifikan antara religiusitas terhadap gaya hidup. Hasil penelitian menunjukkan bahwa terdapat pengaruh yang signifikan dari religiusitas terhadap gaya hidup konsumen muslim toko Artomoro di Ponorogo sebesar 9,9\% dan sisanya 90,1\% dipengaruhi oleh variabel lainnya yang tidak dibahas dalam penelitian ini.
\end{abstract}

Pedoman Sitasi: Miatun, S., \& Santoso, L. (2020). Pengaruh Religiusitas Terhadap Gaya Hidup Konsumen Muslim Di Ponorogo. SERA M BI: Jurnal Ekonomi M anajemen D an Bisnis Islam, 2(2), 113 - 120

DO I: https:/ / doi.org/ 10.36407/ serambi.v2i2.181
Received 06 Mei 2020

Revised 18Jun 2020

A ccepted 25J un 2020

Online first 30 Jun 2020

\section{Paper type}

Literature review

Email Korespondensi*: sumbulatimmiatun@gmail.com

Keywords: business online transaction, islamic perspective

SERAMBI: Jurnal Ekonomi dan Bisnis Islam, Vol 2, N o.2, 2020, pp. $113-120$ elSSN 2685-9904 


\section{Pendahuluan}

Seiring perkembangan zaman dan perkembangan teknologi, kebutuhan masyarakat akan komunikasi dan akses informasi semakin berkembang. Inovasi dari hasil pemikiran manusia semakin lama menjadikan teknologi semakin canggih, cepat dan tanpa batas. Pada awalnya teknologi diciptakan untuk mempermudah komunikasi yang jaraknya sangat jauh sekalipun. Alat komunikasi yang memungkinkan dan sangat memudahkan ini dikenal dengan handphone (Isnaini, 2016). Dengan bertambah dan semakin berkembangnya suatu teknologi, perangkat Handphone semakin bertambah lengkap mulai dari Game, Mp3, Kamera, Radio, dan Koneksi Internet (Kasetyaningsih, 2015). Salah satu bentuk perubahan perilaku yang tampak akibat globalisasi yang terjadi pada para konsumen adalah munculnya perubahan gaya hidup (Saputri, 2016).

Gaya hidup merupakan suatu hal yang tidak dapat dipisahkan dari kehidupan individu maupun kelompok yang merupakan gambaran bagi setiap orang yang mengenakannya serta menggambarkan seberapa besar nilai moral orang tersebut di dalam masyarakat dan di lingkungan sekitarnya serta bagaimana cara orang tersebut hidup. Gaya hidup juga memiliki peran terhadap keputusan pembelian yang dilakukan konsumen. Dengan meningkatnya gaya hidup masyarakat pada zaman modern ini yang terjadi akibat adanya pengaruh yang muncul dalam masyarakat yang mempengaruhi cara berfikir seseorang. Semakin berkembangnya zaman dan semakin canggihnya suatu teknologi, maka penerapan gaya hidup oleh manusia juga semakin berkembang luas dalam kehidupan sehari-hari. Jelas sekali bahwa gaya hidup di dalam suatu masyarakat di lingkungan atau negara tertentu merubah sikap para konsumen serta mengikuti trend yang berkembang pada saat ini (Isnaini, 2016).

Salah satu bentuk perubahan gaya hidup menurut Monks, Knoers dan Haditomo adalah adanya hasrat atau keinginan agar penampilan, gaya tingkah laku, cara bersikap, dan lainlainnya akan menarik perhatian orang lain, terutama kelompok teman sebaya, karena masyarakat ingin diakui eksistensinya oleh lingkungan tempatnya berada. Hal ini tak jarang mengakibatkan masyarakat melakukan berbagai cara agar dapat memenuhi hasratnya tersebut. Salah satunya adalah membeli Handphone pengeluaran terbaru dengan berbagai macam merk dan sistem yang lebih canggih (Saputri, 2016).

Berbagai studi telah mencoba untuk mengeksplorasi faktor-faktor yang mempengaruhi gaya hidup dan dampaknya pada perilaku pembelian. Namun kebanyakan studi lebih berfokus pada dampak gaya hidup, misal nya terhadap niat pembelian (Nora \& Minarti, 2017; Park, 2018; Lee, 2019; Putri, 2019); kepuasan konsumen (Naim, Hamid, \& Wahab, 2019), nilai konsumsi (Antonio \& Astika, 2019); keputusan pembelian (Laksono \& Iskandar, 2019). Studi berbeda dilakukan oleh Kartajaya et al. (2019) yang melakukan clustering untuk mengidentifikasi tipologi gaya hidup fashion yang relevan untuk memprediksi perbedaan individu dalam mengevaluasi produk busana Islami. Melibatkan 697 responden dari empat kota besar di Indonesia (Jakarta, Bandung, Surabaya dan Malang) studi mereka menemukan bahwa ada 11 faktor dan 6 segmen untuk mengelompokkan responden gaya hidup mode Islam. Dapat dinyatakan bahwa konsumen mode Islam memiliki tingkat tinggi atau agama dan gaya berpakaian Syariah.

Telihat bahwa peneitian tentang perilaku konsumen belum didokumentasikan secara komprehensif, terutama terkait dengan religiusitas dan perilaku konsumen (Agarwala, Mishra, \& Singh, 2019). Penelitian ini berupaya untuk menguji hubungan religiusitas dengan gaya hidup sebagai kelanjutan dari studi Kartajaya et al. (2019) yang lebih bertujuan untuk mengelompokkan responden. Religiusitas dalam agama Islam dijadikan sebagai salah satu dasar dalam tumbuh 
kembang seseorang. Prinsip gaya hidup yang berlebihan menganggap bahwa segala sesuatu akan dianggap baik jika hal tersebut telah sesuai dengan kesenangan yang akan diperoleh. Pada dasarnya secara harfiah seseorang yang religius akan selalu berusaha untuk berbuat kebaikan, tidak hanya untuk dirinya sendiri tetapi juga untuk orang lain.

Religiusitas adalah suatu simbol sistem keyakinan, nilai, dan perilaku yang memusatkan berbagai persoalan-persoalan duniawi yang keseluruhan maknanya disimpulkan dalam suatu keyakinan hakiki. Glock dan Strak mengemukakan ada beberapa dimensi dalam religiusitas yaitu keyakinan, ritual, pengamalan, pengetahuan dan pengalaman. Berdasarkan dimensi keyakinan, orang dengan tingkat keyakinan religiusitas yang tinggi akan berperilaku konsekuen dengan ajaran agamanya dalam bersosial dengan masyarakat. Namun disamping itu, hasil penelitian Ernest Harms menunjukkan bahwa remaja lebih mementingkan kesenangan pribadinya daripada masalah religiusitas. Delener dalam Esso dan Dibb menyatakan bahwa religiusitas adalah salah satu faktor pendorong penting dan dapat berpengaruh terhadap perilaku konsumen. Hal ini didasari atas keputusan konsumen untuk membeli produk tergantung kadar keimanan mereka (Nasrullah, 2016). Fokus utama dalam studi ini adalah memahami dampak religiusitas terhadap gaya hidup para konsumen dalam membeli $\mathrm{Hp}$ Android, khususnya dari kalangan konsumen muslim di Kabupaten Ponorogo. Hasil studi ini dapat memberikan kekayaan literature pada studi religiusitas dan gaya hidup konsumen muslim, khususnya di Indonesia.

\section{Kerangka teoritis}

Gaya hidup atau lifestyles didefinisikan sebagai pola di mana orang hidup dan menghabiskan waktu dan uang, mencerminkan aktivitas, minat, dan pendapat seseorang, serta variabel demografis (Blackwellet al., 2001). Variabel psikografis seperti gaya hidup memberikan lebih banyak alasan mendasar perilaku konsumen, sementara demografi memberikan atribut fisik konsumen yang mudah diamati untuk mengidentifikasi kelompok-kelompok yang homogen. Variabel psikografis membantu untuk menjelaskan mengapa mereka membeli, sementara variabel demografis fokus pada siapa yang membeli produk. Lifestyles change lebih cepat daripada nilai (Blackwellet al., 2001), sehingga pemasar harus melacak tren tren gaya hidup sementara dari target dan merefleksikan pengembangan produk, komunikasi pesan, atau strategi promosi. Gaya hidup dibagi menjadi gaya hidup terkait produk yang merupakan aktivitas, minat, dan pendapat tentang produk tertentu (dalam Kertajaya et al., 2019). Gaya hidup adalah pola kehidupan yang diekspresikan dalam keadaan psikografis (Kotler \& Armstrong 2005: 170). Definisi lain dari gaya hidup adalah menunjukkan bagaimana orang hidup, bagaimana menghabiskan uang, dan bagaimana mengalokasikan waktu (Mowen \& Minor, 2002: 282 ). Sumarwan (2002: 56) menyatakan bahwa perilaku gaya hidup seseorang, yaitu bagaimana hidup, menggunakan uangnya dan memanfaatkan waktunya.

Dalam beberapa tahun terakhir, berbagai studi telah mencoba untuk menguji hubungan antara religiusitas dan perilaku konsumen.. Namun, penelitian tentang perilaku konsumen belum didokumentasikan secara komprehensif (Agarwala et al., 2019). Religiusitas dipandang berdasarkan teori kepribadian Kelly yang menjadi dasar penelitian ini. Teori ini digunakan untuk menjelaskan bagaimana religiusitas atau nilai-nilai dan norma agama diaktifkan dalam pengalaman kehidupan mereka. Teori ini berpendapat bahwa konstruk pribadi adalah pola untuk mengantisipasi peristiwa. Studi Agarwala, Mishra, \& Singh (2019) secara komprehensif membuat kerangka konseptual untuk menggambarkan bagaimana dimensi agama tertentu dapat 
menjelaskan mekanisme psikologis. Secara khusus, studi mereka mengusulkan doa (ritual keagamaan), eksklusivisme agama dan retribusi ilahi (keyakinan agama), berhemat (nilai-nilai agama) dan keterlibatan komunitas agama dan identitas agama (komunitas agama) sebagai anteseden yang mungkin mendorong perbedaan yang sebelumnya ditetapkan dalam perilaku konsumen.

\section{Metodologi}

Desain penelitian

Penelitian ini menggunakan pendekatan kuantitatif dengan teknik pengumpulan data yang telah ditentukan dan sangat terstruktur (Hendryadi, Tricahyadinata, \& Zannati 2019). Tujuan studi ini adalah untuk menguji hubungan antar variabel, yang diukur numerik dan dianalisis menggunakan teknik statistik, yaitu regresi linier.

\section{Populasi dan sampel}

Populasi dari penelitian ini adalah konsumen dari Toko Artomoro Ponorogo. Populasi pengunjung sebesar 3.195 yang datang ke Toko Artomoro Ponorogo. Dalam penelitian ini rumus sample yang digunakan yaitu dengan rumus Slovin dengan sampel yang digunakan dalam penelitian ini sebanyak 96,96 yang di bulatkan menjadi 97 responden. Adapun teknik yang diambil dalam pengambilan sampel menggunakan teknik Purposive Sampling dan Quota Sampling. Purposive Sampling adalah teknik pengambilan sampel sumber data dengan pertimbangan tertentu. Sampling kuota yaitu penentuan sampel dari populasi yang mempunyai ciri-ciri tertentu sampai jumlah (jatah) yang dikehendaki (Riduwan, 2012). Ciri-ciri yang dimaksut adalah konsumen muslim di toko Artomoro Ponorogo.

\section{Pengukuran}

Religiusitas adalah keberagamaan, yaitu suatu keadaan yang ada dalam diri seseorang yang mendorongnya untuk bertingkah laku sesuai dengan kadar ketaatannya kepada agama (Rahmat, 2003). Gaya hidup secara luas didefinisikan sebagai cara hidup yang diidentifikasikan oleh bagaimana orang menghabiskan waktu mereka (aktifitas), apa yang mereka anggap penting dalam lingkungannya (ketertarikan) dan apa yang mereka pikirkan tentang diri mereka sendiri dan juga dunia di sekitarnya (Rahmat, 2003).

Tabel 1. Definisi Operasional

\begin{tabular}{|l|l|l|}
\hline \multicolumn{1}{|c|}{ Variabel } & \multicolumn{1}{|c|}{ Definisi Operasional } & \multicolumn{1}{c|}{ Indikator } \\
\hline Religiusitas & Religiusitas adalah suatu keadaan & Yang termasuk religiusitas: \\
& yang ada dalam diri seseorang & - Dimensi Keyakinan \\
& yang mendorongnya untuk & - Dimensi Praktik \\
& bertingkah laku sesuai dengan & - Dimensi Pengalaman \\
& kadar ketaatannya kepada agama & - Dimensi pengetahuan agama \\
& & - Dimensi Konsekuensi \\
\hline Gaya Hidup & Gaya hidup menunjukkan & Yang termasuk gaya hidup: \\
& bagaimana orang hidup, & - Aktivitas \\
& bagaimana mereka & - Minat \\
& membelanjakan uangnya dan & - Opini \\
& bagaimana mereka & \\
& mengalokasikan waktu mereka & \\
\hline
\end{tabular}

Sumber: diolah 


\section{Hasil dan pembahasan}

A nalisis deskriptif

Untuk mendapatkan data mengenai religiusitas dan gaya hidup, peneliti menggunakan metode angket, yaitu angket yang disajikan peneliti berupa pernyataan yang dipilih oleh responden. Dalam penelitian ini yang dijadikan responden adalah masyarakat Ponorogo pembeli Hp Android yang berjumlah 97 responden. Adapun hasil skor Religiusitas, dapat dilihat pada tabel berikut ini

Tabel 2. Analisis deskriptif

\begin{tabular}{|c|c|c|c|c|c|}
\hline N o. & $\begin{array}{c}\text { Skor jawaban } \\
\text { angket religiusitas }\end{array}$ & $\begin{array}{c}\text { Jumlah } \\
\text { Frekuensi }\end{array}$ & No & $\begin{array}{c}\text { Skor jawaban } \\
\text { Gaya hidup }\end{array}$ & $\begin{array}{c}\text { Jumlah } \\
\text { Frekuensi }\end{array}$ \\
\hline 1 & 22 & 1 & 1 & 18 & 2 \\
\hline 2 & 24 & 2 & 2 & 19 & 4 \\
\hline 3 & 25 & 4 & 3 & 20 & 5 \\
\hline 4 & 26 & 13 & 4 & 21 & 9 \\
\hline 5 & 27 & 15 & 5 & 22 & 15 \\
\hline 6 & 28 & 13 & 6 & 23 & 13 \\
\hline 7 & 29 & 8 & 7 & 24 & 9 \\
\hline 8 & 30 & 17 & 8 & 25 & 16 \\
\hline 9 & 31 & 9 & 9 & 26 & 4 \\
\hline 10 & 32 & 2 & 10 & 27 & 7 \\
\hline 11 & 33 & 3 & 11 & 28 & 7 \\
\hline 12 & 34 & 2 & 12 & 29 & 5 \\
\hline 13 & 35 & 3 & 13 & 31 & 1 \\
\hline 14 & 36 & 3 & & & 97 \\
\hline 15 & 37 & 2 & & & Jumlah \\
\hline & Jumlah & 97 & &
\end{tabular}

Sumber: data lapangan, diolah

Dalam data tentang gaya hidup peneliti juga menggunakan metode angket yaitu angket yang disajikan peneliti berupa pernyataan yang dipilih oleh responden. Dalam penelitian ini yang dijadikan responden adalah masyarakat Ponorogo pembeli $\mathrm{Hp}$ Android yang berjumlah 97 responden. Religiusitas konsumen muslim toko A rtomoro di ponorogo tergolong sedang dengan prosentase tertinggi yaitu $77,31 \%$. Gaya hidup konsumen muslim toko Artomoro di ponorogo tergolong sedang dengan prosentase tertinggi yaitu $63,91 \%$.

Pengujian hipotesis

Hasil pengujian hipotesis berdasarkan teknik anal isis regresi ditampilkan pada tabel berikut ini:

Tabel 3. Hasil Regresi

\begin{tabular}{lrrrr}
\hline & Koefisien & se & thitung & \multicolumn{1}{l}{ sig } \\
\hline (Constant) & 15.306 & 2.646 & 5.786 & 0.000 \\
RELIGIUSITAS & 0.293 & 0.091 & 3.238 & 0.002 \\
R square & 0.099 & & & \\
Korelasi & 0.315 & & & \\
Sumber: diolah & & & &
\end{tabular}


Berdasarkan output di atas, diketahui bahwa nilai koefisien regresi variabel religiusitas adalah sebesar 0,293 bernilai positif, sehingga dapat dikatakan bahwa religiusitas berpengaruh positif terhadap gaya hidup. Pengaruh positif diartikan, bahwa semakin meningkat religiusitas maka akan meningkat pula gaya hidup. Pada tabel Coefficients, pada kolom B pada Constant (a) adalah 15,306, sedang nilai religiusitas (b) adalah 0,293, sehingga persamaan regresinya dapat ditulis: $Y=a+b X$ atau $15,306+0,293$

\section{Pembahasan}

Berdasarkan hasil pengujian hipotesis, diperoleh bahwa variabel religiusitas memiliki nilai $\mathrm{t}$ hitung lebih besar dari nilai t tabel $(3,238>1,985)$ dan taraf signifikansi (Sig.) yang lebih kecil dari $0,05(0,02<0,05)$. Hal ini menunjukkan bahwa variabel religiusitas berpengaruh signifikan atau memiliki keterkaitan terhadap gaya hidup konsumen muslim dalam membeli $\mathrm{Hp}$ Android atau dengan kata lain Ha diterima. Diterimanya hipotesis ini mengindikasi bahwa semakin besar religiusitas, maka semakin besar pengaruhnya terhadap gaya hidup konsumen muslim dalam membeli Hp Android. N orma-norma serta perintah dalam agama menjadi sebuah pertimbangan yang besar dalam pembelian $\mathrm{Hp}$ Android untuk memenuhi gaya hidup. Mengingat bahwasannya membeli Hp Android untuk memenuhi gaya hidup yang berlebihan merupakan suatu pemborosan. Hal ini berarti religiusitas merupakan faktor yang menyebabkan seseorang konsumen muslim untuk membeli Hp Android untuk memenuhi gaya hidup ataupun tidak.

Dari koefisien korelasi diketahui bahwa korelasi antara variabel Religiusitas dan variabel Gaya Hidup memiliki nilai Person Corellation sebesar 0,315 atau 31,5\%. Karena nilai koefisien dibawah 50\% maka dapat disimpulkan bahwa antara variabel religiusitas dan gaya hidup memiliki hubungan yang rendah. Angka koefisien korelasi yang positif $+0,315$ menunjukkan arah hubungan yang positif pula. Artinya, jika nilai variabel religiusitas tinggi, maka nilai variabel gaya hidup (Y) akan tinggi pula. Singkatnya koefisien korelasi adalah tingkat keeratan hubungan antara variabel-variabel.

Dari hasil penelitian ini juga diketahui nilai koefisien determinasi sebesar sebesar 0,099 atau 9,9\%. Hal ini berarti 9,9\% gaya hidup konsumen muslim dalam membeli Hp Android dipengaruhi oleh religiusitas. Sedangkan sisanya yaitu 90,1\%, yang artinya gaya hidup dipengaruhi oleh variabel-variabel lainnya yang tidak diteliti dalam penelitian ini. Artinya, yang menjadi faktor dominan yang mempengaruhi gaya hidup konsumen muslim dalam membeli $\mathrm{Hp}$ Android adalah selain faktor religusitas.

Hasil studi ini dapat menambah wawasan empiris pada hubungan antara religiusitas dan perilaku konsumen. Seperti penjelasan Agarwala et al. (2019), penelitian tentang perilaku konsumen belum didokumentasikan secara komprehensif. Penelitian ini mengadopsi teori kepribadian Kelly sebagai landasan kerja untuk menjelaskan bagaimana religiusitas atau nilainilai dan norma agama diaktifkan dalam pengalaman kehidupan seseorang. Sejalan dengan teori ini, religiusitas terbukti memiliki dampak signifikan terhadap gaya hidup sehingga dapat menjadi bukti empiris di bidang ini. Sejalan dengan itu, studi ini juga mendukung berbagai studi lainnya di bidang pemasaran, seperti hubungan antara religiusitas pada sikap dan niat beli (Souiden \& Rani, 2015).

\section{Kesimpulan}

Penelitian ini bertujuan untuk mengetahui dampak religiusitas terhadap gaya hidup para konsumen dalam membeli $\mathrm{Hp}$ Android, khususnya dari kalangan konsumen muslim di Kabupaten Ponorogo. Hasil studi menemukan bahwa secara positif dan signifikan, religiusitas 
dapat menjelaskan gaya hidup konsumen yang diteliti. Implikasi temuan ini adalah religiusitas yang seringkali didasarkan pada agama tertentu dapat memberikan dampak pada bagaima seseorang mengikuti gaya hidup tertentu karena dasar keyakinan dan nilai-nilai mereka, termasuk kebiasaan berpakaian, diet, dan urusan ekonomi. Kondisi ini perlu dipahami oleh para pemasar karena gaya hidup seseorang dengan dasar keyakinan tertentu akan berbeda, dan oleh karenanya, keputusan mereka untuk mengkonsumsi atau menggunakan produk tertentu akan berbeda.

Sebagai hasil studi ilmiah, penelitian ini tentu memiliki berbagai keterbatasan. Pertama, studi ini hanya dilakukan pada satu wilayah sehingga generalisasi hasil masih perlu dilakukan secara hati-hati. Kedua, faktor penentu gaya hidup hanya menggunakan satu variabel yaitu religiusitas. Didasarkan pada keterbatasan tersebut maka riset berikutnya perlu memperluas wilayah studi dengan mengambil sampel yang lebih besar di beberapa wilayah di Indonesia. Selain itu, variabel lain yang kemungkinan dapat mempengaruhi gaya hidup seperti tingkat pendapatan dan pendidikan perlu juga mendapatkan perhatian untuk diteliti.

\section{Daftar Pustaka}

Antonio, F., \& Astika, P. (2019). The Antecedents of Consumption Value and Its Impact on Customer Behavior; a Study of Batik Cloth on Non-Javanese Indonesian Millennials. International Journal of A pplied Business and International M anagement, 4(1), 46-58.

Athanasou, J., \& King, N. (2002). Job satisfaction and organizational citizenship behaviour: A study of Australianhuman-service professionals. Journal of Managerial Psychology, 17(4), 287-297

Agarwala, R., Mishra, P., \& Singh, R. (2019). Religiosity and consumer behavior: A summarizing review. Journal of $M$ anagement, Spirituality \& Religion, 16(1), 32-54.

Hendryadi, H., Tricahyadinata, I., \& Zannati, R. (2019). Metode Penelitian: Pedoman Penelitian Bisnis dan A kademik. Jakarta: LPM P Imperium.

Kartajaya, H., Iqbal, M., Alfisyahr, R., Devita, L. D. R., \& Ismail, T. (2019). Segmenting Islamic fashion lifestyle on Indonesian woman. Research Journal of Textile and A pparel. Vol. 23 No. 4, pp. 306-322.

Laksono, D. D., \& Iskandar, D. A. (2018). Pengaruh Gaya Hidup Dan Pendapatan Terhadap Keputusan Pembelian Helm Kbc. Jurnal Riset M anajemen dan Bisnis (JR M B) Fakultas Ekonomi UN IAT, 3(2), 145-154.

Lee, H. (2019). The effect of anti-consumption lifestyle on consumer's attitude and purchase intention toward commercial sharing systems. A sia Pacific J ournal of $M$ arketing and Logistics.

Nora, L., \& Minarti, N. S. (2017). THE ROLE OF RELIGIOSITY, LIFESTYLE, ATTITUDE ASDETERMIN ANT PURCHASE INTENTION. I M C 2016 Proceedings, 1(1).

Parks, J. C. (2018). Identification of brand personality attributes of southern lifestyle brands and its impact on perceived quality, brand attitude, and purchase intention (Doctoral dissertation, University of Alabama Libraries).

Naim, A. M., Hamid, M. L. A., \& Wahab, M. Z. H. (2019). The Roles of Lifestyle, Future Need and Customer Preferences in Customer's Satisfaction on Islamic Banks Products and Services. The Journal of M uamalat and Islamic Finance R esearch, 60-76.

Putri, Y. A. (2019). Pengaruh bauran promosi dan gaya hidup terhadap minat beli pada kedai kopi serasi. Jurnal M anajemen Strategi dan A plikasi Bisnis, 2(2), 137-144.

Souiden, N., \& Rani, M. (2015). Consumer attitudes and purchase intentions toward Islamic banks: the influence of religiosity. International Journal of Bank $M$ arketing. 


\section{Profil Penulis}

Sumbu Latim Miatun dan Lukman Santoso adalah mahasiswa dan dosen di Institut Agama Islam N egeri Ponorogo. Penulis dapat di hubungi di email: sumbulatimmiatun@gmail.com

Accepted author version posted online: 20 June 2020

$$
\text { (c) (1) }
$$

(C) 2020 The Author(s). This open access article is distributed under a Creative Commons Attribution (CC-BY) 4.0 license 